\title{
Refuge
}

Canada's Journal on Refugees

revue canadienne sur les réfugiés

\section{Running on Empty: Canada and the Indochinese Refugees, 1975-1980, by Michael J. Molloy, Peter Duschinsky, Kurt F. Jensen, and Robert Shalka}

\section{Mireille Paquet}

Volume 34, Number 1, 2018

Intersectional Feminist Interventions in the "Refugee Crisis"

URI: https://id.erudit.org/iderudit/1050858ar

DOI: https://doi.org/10.7202/1050858ar

See table of contents

Publisher(s)

Centre for Refugee Studies, York University

ISSN

0229-5113 (print)

1920-7336 (digital)

Explore this journal

Cite this review

Paquet, M. (2018). Review of [Running on Empty: Canada and the Indochinese Refugees, 1975-1980, by Michael J. Molloy, Peter Duschinsky, Kurt F. Jensen, and Robert Shalka]. Refuge, 34(1). https://doi.org/10.7202/1050858ar

Copyright (c) Refuge: Canada's Journal on Refugees, 2018 Creative Commons Attribution NonCommercial 4.0 International License (c) (i) (8)
This document is protected by copyright law. Use of the services of Érudit (including reproduction) is subject to its terms and conditions, which can be viewed online.

https://apropos.erudit.org/en/users/policy-on-use/ 
consequences such poisoning discourses can have. Reports of increasing racism in the aftermath of the UK referendum on EU membership only heighten the pertinence of this work.

The project provides an excellent example of conducting collaborative research and producing anti-racist and feminist-situated knowledge (4), and a kind of public scholarship (161) that is informed by academics like W. E. B. Du Bois, bell hooks, or Audre Lorde. Part of such research is the commitment to make the knowledge accessible to an audience beyond academia. Not only is the book written accessibly, the researchers also communicated their thoughts both during and at the end of the project, including through blog posts, tweets, a short film, and a conference that included beyond-text formats such as performances. Ultimately, the authors contribute to imagining more inclusive futures and to alternative forms of knowledge production.

Andrea Filippi is an independent researcher. The author can be reached at andrea.filippi@unine.ch.

\section{Running on Empty: Canada and the Indochinese Refugees, 1975-1980 $\sim$ \\ Michael J. Molloy, Peter Duschinsky, Kurt F. Jensen, and Robert Shalka, foreword by Ronald Atkey Montreal and Kingston: McGill-Queen’s University Press, 2017, 612 pp.}

$R$ unning on Empty documents the Canadian resettlement operation of about 70,000 refugees from the Indochinese region between 1975 and 1980. It is a hefty monograph, rich in details and anecdotes. It will serve as a reference for teaching this period and, because of the novel information it includes, might be used as a starting point for new research. In addition to making a clear empirical contribution, the book is original in its focus on the role of the public administration over this period. The public service is presented as a site of innovation in managing an unprecedented resettlement effort. The engagement and devotion of public servants is an important thread throughout the story, and the interactions between elected officials, high-level public officials, and federal departments are explored with enough detail to account for the different ways in which each influenced the others.

Running on Empty contributes to current efforts to illuminate the workings of the Canadian state from the inside, when it comes to refugee, immigration, and border operations. Besides historical literature, it is an interesting historical companion to Mountz's Seeking Asylum: Human Smuggling and Bureaucracy at the Border (University of Minnesota Press, 2010) and Satzewich's Points of Entry: How Canada's Immigration Officers Decide Who Gets In (UBC Press, 2014). It also provides a different representation of mid- and high-level public servants working in immigration in this period. Instead of the actors described by the historical work on the Canadian immigration bureaucracy as engaged in control, exclusion, and boundary making, the characters of this story are determined to help and to ensure due process. Whether readers will be convinced or not, Running on Empty attempts to show that each generation of public servants contributed differently to Canada's refugee policy.

Stemming from a collaboration between the Canadian Immigration Historical Society, the authors and officers active in resettlement operation, the book is divided into three sections: the history of Canada's involvement with the Indochinese refugees, the resettlement operations in Southeast Asia, and the work of welcoming the refugees in Canada. It rests on archival materials, including neverreleased files such as Cabinet memoranda, and includes testimonials from officers active abroad and in Canada. The first section reviews Canada's refugee policy and the events leading to the fall of Saigon, with an eye on the positions taken by Canada as part of a changing geopolitical context. It follows policies, laws, and politics chronologically from 1975 to the 1980s. Chapter 4 on the 1976 Immigration Act is a great resource for teaching about the inclusion of new provisions into legislation and about the beginnings of the private sponsorship program. Notable in this section is
(C) Author(s), 2018. This open-access work is licensed under a Creative Commons Attribution-NonCommercial 4.0 International Licence, which permits use, reproduction, and distribution in any medium for non-commercial purposes, provided the original authorship is credited and the original publication in Refuge: Canada's Journal on Refugees is cited.
Cette ouvre en libre accès fait lobjet d'une licence Creative Commons Attribution-NonCommercial 4.o International License, laquelle autorise l'utilisation, la reproduction et la distribution de l’euvre sur tout support à des fins non commerciales, pourvu que l'auteur ou les auteurs originaux soient mentionnés et que la publication originale dans Refuge: revue canadienne sur les réfugiés soit citée. 
also chapter 7, which documents "innovations on the run." This chapter really demonstrates the operational flexibility demanded during that period and how public servants had to draw inspiration from unexpected places (e.g., the Berlin airlift) to respond to the new challenges they faced. Section 2 provides a vivid and diverse portrait of the day-to-day work over this period. Using interviews, narratives, and even original reports produced in the field, chapters in this section highlight the complexity of the work of these officers in relation to headquarters' (Ottawa) misunderstandings of the realities in the field, lack of resources, but also simple human factors that affected the officers' working conditions. The inclusion of a chapter on Quebec's operations in Southeast Asia is a commendable contribution to our understanding of the lesser known actions of the province during that period. This section is the most original of the book. At the same time, it could have benefited from a richer discussion regarding the decisions of what to include in this section, e.g., specific issues and events. Likewise, more contextualization of the individual narratives included would have been helpful. Section 3 focuses on the resettlement operations as they unfolded in Canada. It includes accounts of arranging the operations at the airport, coordination between government stakeholders, and the work of the refugee settlement officers. Running on Empty also includes a useful chronology of the Indochinese refugee movement to Canada, pictures of the operations, maps of the areas described, and biographies of all of the officers who shared their experience. It concludes with some lessons learned from this extraordinary operation.

Running on Empty is hesitant to make any theoretical claims and resists making strong political statements. While this may be frustrating for some readers, it should also be seen as an opportunity. It provides scholars with a wealth of empirical information and testimonies to build on. It also shows the lasting influence of this period on current policies and operations, despite legislative changes and new technologies. It is a timely publication, as Canada is now starting to take stock of the 2015 Syrian resettlement initiative. Parallels and contrasts can be drawn throughout the book. The most important being, undoubtedly, that the "size of the commitment [to resettle Indochinese refugees] came as a surprise to public servants" (454), something that is reminiscent of Trudeau's post-election commitment to resettle 25,000 Syrian refugees in a year. While technologies, the size of the federal administration, and the overall geopolitical context have evolved, chances are that the future work on the 2015 episode will stress similarities with the 1975-80 period such as innovation despite limited resources, officers' dedication in the field, and the contribution of the private sponsorship program. At the same time, the book is a sobering reminder not to prematurely celebrate Canada's current resettlement efforts. Considering the major differences that are the unprecedented size of global displacement and growth of the capacity of the Canadian state, the story told by Running on Empty makes the 2015 resettlement targets less impressive, to say the least.

Mireille Paquet is an assistant professor of political science at Concordia University and the co-director of Concordia's Centre for Immigration Policy Evaluation. She can be contacted at mireille.paquet@concordia.ca.

\section{The Child in International Refugee Law

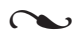 \\ Jason M. Pobjoy \\ Cambridge: Cambridge University Press, 2017, 317 pp.}

I $\mathrm{n}$ his magnificent new book Jason M. Pobjoy methodically and persuasively builds the case for a thorough reset of international refugee law in order to address the gap in protection for refugee children. Despite the fact that almost half of the world's refugees are children, refugee law tends to make them invisible, using an adult-centred lens that fails to capture the predicament of children and youth who are refugees, resulting in incorrect assessments of refugee status.
(C) Author(s), 2018. This open-access work is licensed under a Creative Commons Attribution-NonCommercial 4.o International Licence, which permits use, reproduction, and distribution in any medium for non-commercial purposes, provided the original authorship is credited and the original publication in Refuge: Canada's Journal on Refugees is cited.
Cette ouvre en libre accès fait l'objet d'une licence Creative Commons Attribution-NonCommercial 4.0 International License, laquelle autorise l'utilisation, la reproduction et la distribution de l'œuvre sur tout support à des fins non commerciales, pourvu que l'auteur ou les auteurs originaux soient mentionnés et que la publication originale dans Refuge: revue canadienne sur les réfugiés soit citée. 